\title{
BILINGUAL EDUCATION OF MINORITIES: ALWAYS THE BEST SOLUTION?
}

\begin{abstract}
Многи истраживачи чврсто верују да примена двојезичног образовног модела може истовремено да очува идентитет одређених етно-културних мањина и да олакша њихову друштвену интеграцију. На пример, Владимир Кулик је истакао предлог за решавање проблема образовања две мањине у Украјини: Кримских Татара и Транскарпатских Мађара. Он предлаже покретање двојезичног образовања у тим контекстима. Међутим, након двадесет година истраживања социјалних, културних и социолингвистичких аспеката транскарпатског мађарског контекста, не можемо избећи реакцију на чланак међународно познатог стручњака. Напомињемо да је питање образовања мањина компликованије него што је описано у поменутом чланку. Допринос расправи представљају увиди нас који смо упућени у то, као и погледи на ово централно питање.
\end{abstract}

Кључне речи: двојезично образовање, језици националних мањина, језик државе, Транскарпати, Украјина.

\section{Introduction}

Volume 43 of Compare: A Journal of Comparative and International Education published an article by Volodymy Kulyk (2013). The author draws conclusions relating to the education systems of two minorities in Ukraine, the Crimean Tatars and the Transcarpathian Hungarians based on some semistructured interviews and altogether 255 completed questionnaires.

The study seems to suggest that the author has managed to cut the Gordian knot of minority education: he found an educational model which simultaneously ensures the preservation of ethno-cultural identity and facilitates social integration. According to the conclusion of the internationally known researcher, by introducing bilingual education, it is possible to solve the education problems of two Ukrainian minorities (the 
Crimean Tatars and the Transcarpathian Hungarians) that are significantly different from each other.

While we do not doubt Professor Kulyk's expertise and good intentions, we would like to share our thoughts related to his research results and conclusions. Our views are rooted in our own research, which we have been conducting for about twenty years, investigating the Transcarpathian Hungarian educational system according to various criteria. In our study, we explain that the question of minority education is impossible to remove from the complex context in which it operates.

\section{Relationship between mother tongue education and language maintenance in Ukraine based on statistical data}

According to the official data of the (latest) 2001 census, the number of people of Hungarian nationality was 156,566 (0.32\% of the total population). The number of those with Hungarian as their mother tongue was somewhat higher: $161,618(0.33 \%) .96 .77 \%$ of those with Hungarian nationality and $98.21 \%$ of those with Hungarian as first language live in a single region in Ukraine: Transcarpathia. The number of Hungarian nationals in Transcarpathia (which is found in the western part of the country) is 151,516 and their ratio within the region's total population is $12.08 \%$. The number of citizens with Hungarian as their mother tongue is 158,729 and their ratio within the population of the region is $12.65 \%$.

The Hungarian education system is one of the most developed ones in the whole of Ukraine. According to the education model now applied in Transcarpathia, every subject is taught in the learners' mother tongue (Hungarian) in the schools with Hungarian language as the means of instruction; the state language and one or two foreign languages are separate school subjects. According to the data of the Ministry of Education and Science of Ukraine and those of the Transcarpathian Hungarian Pedagogical Association, instruction in Hungarian is carried out in 70 kindergartens and 70 general secondary schools in the region. In another 32 general secondary schools, instruction is carried out in Ukrainian and Hungarian (in parallel forms, one is taught in Ukrainian, the other in Hungarian). More than 15,000 children study in schools with Hungarian as 
the language of instruction. Students can obtain a degree in several majors after studying in Hungarian both at Uzhhorod National University and at Ferenc Rákóczi II Transcarpathian Hungarian Institute.

If we examine the data presented in Table 1 and Figure 1, we can notice an interesting connection (Csernicskó \& Ferenc 2010: 340-342). In the rest of Ukraine as well as in Transcarpathia, the nationality and mother tongue coincide mainly in those nationalities which have a school network teaching in the pupils' first language (Russians, Romanians, and Hungarians); however, in the case of those national minorities that do not have their own schools (or only partly), the ratio of those speaking another first language, other than the language of their ethnicity is significantly higher (Gypsies, Byelorussians, Germans, and Slovaks).

The data shows the correlations of language identity, language maintenance and the language of instruction demonstrated by the language of the majority (Ukrainians) and those of the 13 minority communities.

Figure 1. The ratio of those considering the language of their nationality as their mother tongue in the whole of Ukraine and in Transcarpathia (2001 census data)

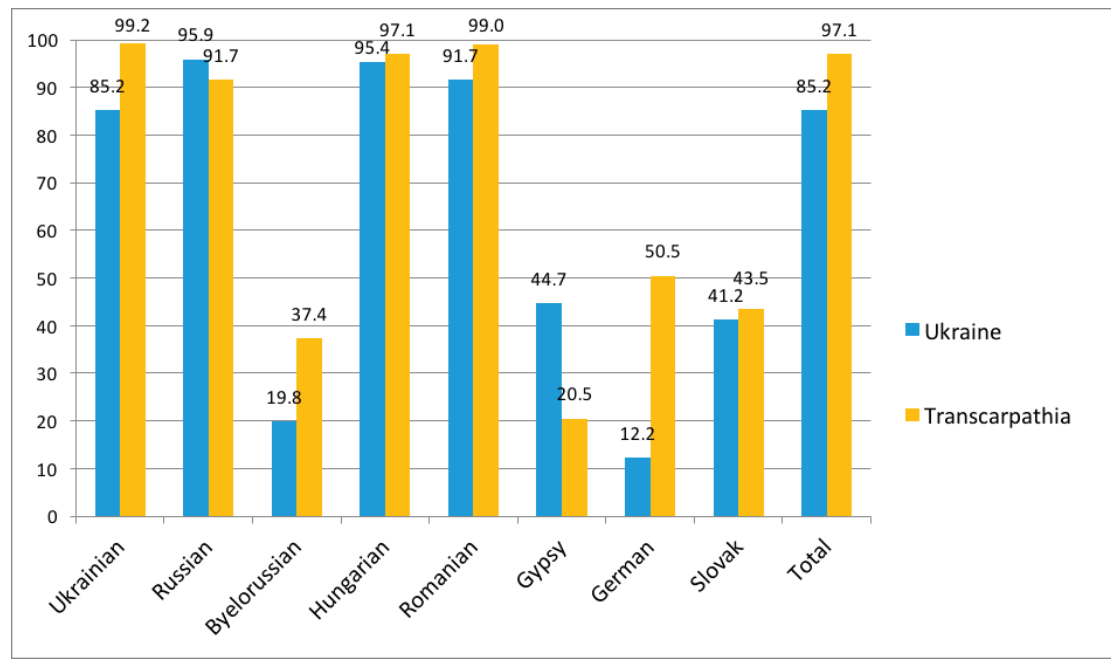


Table 1. The languages of 13 minority communities of Ukraine at various levels of education

\begin{tabular}{|c|c|c|c|c|c|c|c|c|}
\hline $\begin{array}{l}\text { Minority } \\
\text { language }\end{array}$ & $\begin{array}{c}\text { Mother } \\
\text { tongue in } \\
\text { pre-school } \\
\text { education }\end{array}$ & $\begin{array}{l}\text { Instruction } \\
\text { of National } \\
\text { culture, } \\
\text { traditions }\end{array}$ & $\begin{array}{l}\text { Mother } \\
\text { tongue as } \\
\text { optional } \\
\text { school } \\
\text { subject }\end{array}$ & $\begin{array}{c}\text { Mother } \\
\text { tongue as } \\
\text { compulsory } \\
\text { school } \\
\text { subject }\end{array}$ & $\begin{array}{l}\text { Mother } \\
\text { tongue as the } \\
\text { language of } \\
\text { instruction } \\
\text { (Forms 1-4) }\end{array}$ & $\begin{array}{c}\text { Mother } \\
\text { tongue } \\
\text { as the } \\
\text { language of } \\
\text { instruction } \\
\text { (Forms } \\
5-11) \\
\end{array}$ & $\begin{array}{l}\text { Mother } \\
\text { tongue as the } \\
\text { language of } \\
\text { instruction } \\
\text { in technical } \\
\text { training }\end{array}$ & $\begin{array}{l}\text { Mother } \\
\text { tongue } \\
\text { taught in } \\
\text { higher } \\
\text { education }\end{array}$ \\
\hline Byelorussian & & & + & & & & & \\
\hline Bulgarian & & + & + & + & + & + & & + \\
\hline Gagaus & & + & + & + & & & & \\
\hline Greek & & + & + & + & & & & + \\
\hline Yiddish & & + & + & + & & & & + \\
\hline Crimean Tatar & & + & + & + & + & + & & + \\
\hline Polish & + & + & + & + & + & + & & + \\
\hline Hungarian & + & + & + & + & + & + & + & + \\
\hline Moldavian & + & + & + & + & + & + & & + \\
\hline German & $*$ & & * & $*$ & $*$ & $*$ & $*$ & $*$ \\
\hline Russian & + & + & + & + & + & + & + & + \\
\hline Romanian & & + & + & + & + & + & & + \\
\hline Slovak & & + & + & + & + & & & + \\
\hline
\end{tabular}


The data demonstrates that a language shift is at an advanced stage in communities which do not have their own schools where instruction is in the students' mother tongue. In spite of the fact that Byelorussians are the second largest minority (behind the Russians) in Ukraine, there are no schools with Byelorussian as the language of instruction and only 19.79\% of them claim that their ethnicity is the same as their first language. In contrast to the Byelorussians, Romanians and Hungarians, for instance, are devoted both to their language and to their schools. It is, of course, not easy to decide whether the high number of people who maintain their own language coincidentally can also learn in their own language or whether they are devoted to their schools because they are also devoted to maintaining their mother tongue. However, it is quite probable that the two indicators correlate and reinforce each other.

\section{Language skills as an essential element of integration}

As a rule, minorities have three options: integration, assimilation or segregation. The necessary instrument of integration is bilingualism: having a command of the majority language ensures the opportunity of fullscale participation in social life, while mother tongue maintenance ensures the preservation of one's own identity and culture. Kulyk sees the path to integration and to acquiring the necessary language skills for it in the introduction of bilingual programmes.

Bilingualism is also a stage in the process of assimilation, but only as a transitional phenomenon. It is only present until the minority community gradually undergoes a complete language shift and becomes a new part of the monolingual majority community, generally taking over the new culture and identity as well (or perhaps also maintaining some marginal elements of their former culture and identity).

Segregation does not require bilingualism. But first language monolingualism, consequently, does not facilitate either horizontal or vertical mobility; it isolates the individual in his own community.

In his study, Kulyk points out that pupils of Transcarpathian schools with Hungarian as the language of instruction do not acquire the state language at a level required for a successful social integration. The results of 
several investigations also support this claim (Csernicskó 2011). At this point, we would like to elaborate on only one type of data: in accordance with Decree No1171 of the Minister of Education issued on 25 December, 2008, applicants to tertiary education (applying for any majors) must pass the very same central examination in 'Ukrainian language and literature' in the whole country. In 2008, 8.38\% of all applicants did not pass the Ukrainian exam and thus did not achieve the minimum score required for admission to tertiary education. This ratio was $9 \%$ in 2009. In Transcarpathian Hungarian schools, the ratio of students not passing the Ukrainian exam was $29.58 \%$ and $44 \%$ in the two years respectively (Csernicskó \& Ferenc 2010: 334-335). In 2015, the 'Ukrainian language and literature' exam was compulsory not only for those who wished to get admitted to tertiary education but for every single school-leaver. In the whole of Ukraine, $8 \%$ of school-leavers failed the exam. In Transcarpathia, the ratio of failures among school-leavers of Hungarian schools was 63\% (Figure 2).

Figure 2. Ratio (in percentage) of examinees who failed the Independent Testing in 'Ukrainian language and literature' (i.e. did not obtain the minimum score needed to be admitted to tertiary education) in Ukraine and in the Transcarpathian Hungarian schools

(2008, 2009, 2015). Sources: Csernicskó \& Ferenc 2010: 334 and LTI 2015.

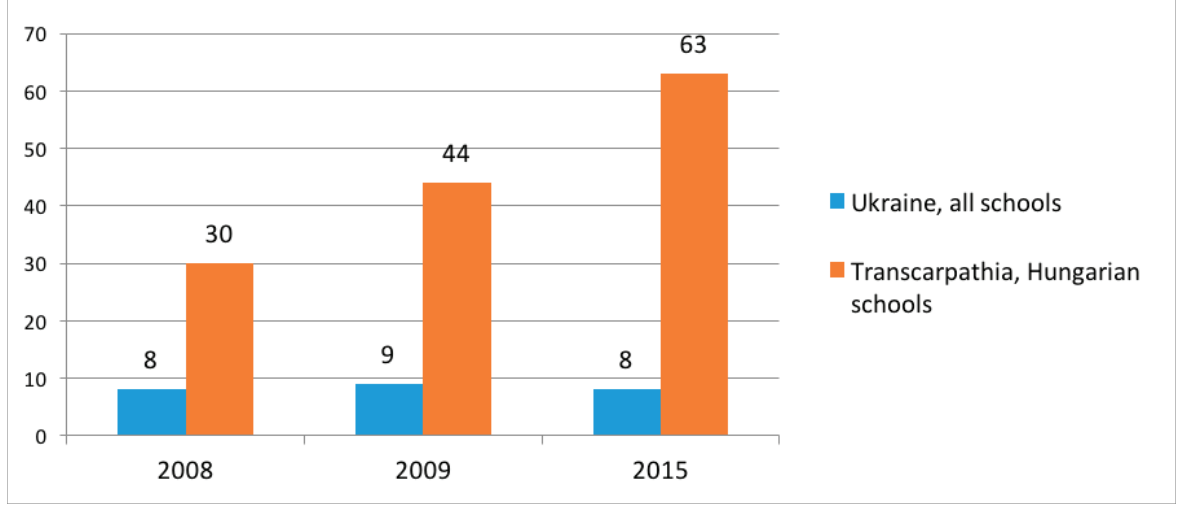

If we consider only these data, we must agree with Kulyk: although Transcarpathian Hungarian schools are successful in reproducing ethnolinguistic identity, their pupils do not acquire the state language at a level that enables their successful social integration into Ukrainian society. It 
seems that schools teaching all the school subjects in Hungarian "lock up" Transcarpathian Hungarians in a (language) ghetto. However, the situation is more complex than that.

The way of interpreting the concept of integration matters a great deal. Integration does not only mean same opportunities. For instance, Skutnabb-Kangas \& Cummins (1988: 393) claim that social justice does not lie in the similarity of possibilities but in the similarity of achievements. However, it can be clearly seen from the data of the 'Ukrainian language and literature' examination that the achievements of school-leavers of Hungarian schools and Ukrainian schools are far apart.

From all this, Kulyk draws the conclusion that as soon as bilingual schooling is launched, the problem will be solved. With this, the expert from Kyiv takes sides with those researchers who believe that the necessity of social integration and mobility is superior to language and identity maintenance. Based on this principle, Edwards (1984: 301) suggests a transitional programme (i.e. bilingual schooling) for minorities. Patten (2001: 701) also argues that language ghettos should be prevented. This logic implies that the successful social integration of minorities is hindered by the minority language, and minority students would be more successful if they acquired the state language as soon as possible. This viewpoint, however, places integrity before language and ethnic identity.

Kulyk is not the first to suggest the introduction of bilingual education in Ukraine. Some time after the Orange Revolution in 2004, Decree No. 461 was issued on 26 May, 2008 by Ivan Vakarchuk, Minister of Education at the time. In order to improve the quality of teaching the Ukrainian language, it prescribed the introduction of the following educational model (Csernicskó \& Ferenc 2010: 333): Forms 1-4 are taught in Hungarian (the students' mother tongue), the state language is introduced in Form 1, while a second foreign language is taught as a school subject from Form 2 onwards. Forms 5-9 have bilingual instruction. The history of Ukraine is taught in two languages starting as of Form 5 both in the students' mother tongue and in Ukrainian (at the expense of optional hours in the curriculum). In Form 6 and onwards, Ukrainian history is taught exclusively in Ukrainian. From Form 6, another subject is taught in two languages (geography). In Form 7, mathematics is added to the list, and in the subsequent 
years, these subjects are only taught in the state language. By the end of the upper primary education (Form 9), the majority of the school subjects are taught in Ukrainian. Theoretically, secondary school (Forms 10-11) provides bilingual instruction, but subjects taught in the state language prevail, and in practice, only Hungarian language and (integrated) literature are taught in Hungarian, all the other subjects are taught in Ukrainian. This educational model corresponds to the transitive program (SkutnabbKangas 1990: 13).

Several unanswered questions have emerged related to the educational model described above. The ministry did not clearly define, for instance, whether to teach compulsory classes solely in the students' mother tongue, while optional lessons are exclusively in Ukrainian.

Is it possible that not only one but two different teachers teach the same subject in the same form (one of them teaches in Hungarian, while the other teaches the children in Ukrainian)? If two teachers hold the lessons, do both of them give marks and evaluate the learners' knowledge and performance or only one of them? If only one teacher evaluates them, should the mark reflect the class performance in the students' mother tongue or that in Ukrainian? If marks are given in both the Hungarian classes and the Ukrainian ones, will the child have two marks in, say, mathematics? Which language should be used when writing a test or when answering the teacher's questions orally? What will happen to the child whose knowledge of Ukrainian is poor but is excellent at mathematics, and vice versa, the child who speaks the state language very well, but the multiplication table already causes great difficulties for him? What kind of textbooks should be used: Ukrainian ones, their Hungarian translations, or both? If both should be used, who will finance the purchase of the second textbook: the state or the parents? Will there ever be bilingual textbooks, visual aids or teaching materials needed for bilingual education? Who will deal with the teachers' language training and development?

The Ministry of Education tried to respond to the above questions a little too late. The ministry wished to launch bilingual education as early as 1 September, 2008, whereas the detailed description of the programme did not appear on the website of the ministry until 1 September, 2009. The educational establishments obtained the methodological guide in the form 
of an official letter (No1/9-581) dated on 28 August, 2009 signed by P. Polianski, Deputy Minister of Education and received it at the beginning of September.

The six-page long methodological guide describes in detail how to organize bilingual education in the schools with national minority languages as the means of instruction. The meaning of bilingual education was defined for the first time by the government in this document. The government considers bilingual education a school programme in which the students' mother tongue and the state language are simultaneously present in one and the same class. That is, the Ukrainian language and the students' first language are present in the teaching process not only as school subjects but as the means of instruction. The description especially focuses on the separation of languages. Code switching must always be marked. Switching from one language to the other must be introduced with the help of phrases such as 'This is how it is called in Hungarian.', 'Attention, please! We will switch to Hungarian.', or perhaps with questions like 'How would you say that in Ukrainian?' Pupils must regularly be reminded to separate the two languages: a sentence started in one language should be finished in the same language. Teachers have to correct linguistically 'mixed' utterances. The ministry emphasizes that every subject-related term must come up in the lesson both in Ukrainian and in the students' mother tongue. The essential points that are elaborated on by the Hungarian speaking teacher must be put down briefly on the board and in the learners' notebooks in Ukrainian (using entire phrases i.e. not only the terms, but the terms in context). Bilingual 'technical' dictionaries should also be used (Csernicskó \& Ferenc 2010: 333).

The model depicted in the methodological guide undoubtedly has several positive elements. Unfortunately, however, the Ukrainian state has not created the necessary conditions for its successful and efficient application.

1. The Ministry of Education did not initiate the introduction of changes in pre-service and in-service teacher training in higher educational establishments. This means that the state prepared neither the language teachers nor the subject teachers for the practical use of the bilingual educational model. 
2. Schools obtained either only Hungarian books or only Ukrainian ones. Bilingual textbooks have not been prepared. Neither has the state commissioned authors or publishers to devise and edit such books. The government wished to implement bilingual education based on monolingual textbooks.

3. The curriculum, textbooks, and requirements of the subject 'Ukrainian Language' have not changed.

4. No answer has been given to the question of how the same amount of material can be taught in bilingual schools as in schools with Ukrainian as the sole language of instruction, since a significant amount of time must be devoted to teaching the state language itself, Ukrainian.

5. The impact of using two languages as the means of instruction on the acquisition of the subject content is not known. From the guidelines of the ministry, it seems that the most crucial objective in minority bilingual programmes was to have the pupils acquire the state language at an advanced level, while the content subjects would be of secondary importance.

6. There are no clear-cut guidelines whether to take the learners' language skills into account or not when giving marks in, say mathematics or biology. As things stand, teachers in one school may act in one way, while in another, they will assess students differently. There may be schools where the pupils' knowledge of Ukrainian will play a significant part in their mark in chemistry, while in another school this factor will not have any impact on the pupils' marks.

In addition to the inadequate preparation of bilingual education, some other concerns also arise. The biggest problem is that the programme is recommended by the ministry only in schools for national minorities; majority schools continue to use only a single language of instruction: Ukrainian. It is also quite problematic that the development and maintenance of minority mother tongues are not mentioned in the documents on bilingual education programmes in any way whatsoever, not even as an intention. This suggests that the maintenance of these languages is not among the objectives of the state. 
Introducing bilingual education exclusively in minority schools interprets the integration of minorities as a general right to study in the state language and achieve in the state language (Csernicskó \& Ferenc 2010).

Fishman (1988/1992: 169) calls this type of integration as 'We-onlywant-to-liberate-them-from-their-ethnic-self-imprisonment' syndrome. The interpretation of the role of integration in minority education by Ukraine, or Edwards (1984), Patten (2001) and Kulyk (2013) disregards the intention of minorities to maintain their own language. However, many experts (e.g. Skutnabb-Kangas, Kontra \& Phillipson 2006) do not agree with this interpretation. Skutnabb-Kangas (1990: 13) does not recommend the application of the transitional programme, with the rationale that " $\mathrm{A}$ transitional programme is a more sophisticated version of submersion programmes, a more 'human' way of assimilation."

We totally agree with Kulyk in that Transcarpathian Hungarians have to master the Ukrainian language for their own sake. We also agree that the language skills in Ukrainian of those who study in Hungarian schools is insufficient, and that the quality of teaching Ukrainian is bad in most of these programmes. Neither the Ministry of Education, nor Kulyk asks the question: why is the standard of teaching Ukrainian in e.g. Transcarpathian Hungarian schools so low?

The right to learn a language is a fundamental human right (SkutnabbKangas 1999: 58). It seems, however, that quarter of a century of independence was not enough for the Ukrainian state to create the necessary conditions for the Hungarians living in the country to exercise this right even during her quarter-century-long independence (Csernicskó 2015).

\section{Different situations, same requirements}

The educational policy in Ukraine interprets the concept of 'similar chances' in a peculiar way. We have mentioned that the subject 'Ukrainian language' means quite different things in Ukrainian and in Hungarian schools. This is also reflected in the number of hours spent teaching the subject. If we examine the data in Table 2, we can see that there was a significant difference between the numbers of weekly hours spent teaching Ukrainian in the academic year 2015/2016 in the two types of schools. 
Letter No 1/9-253 issued on 22 May, 2015 defines the number of hours for the school year 2015/16. According to this, no alterations were made regarding the language-literature subjects. Decree No855 issued by the same ministry on 7 August, 2015, however, did make modifications regarding the above-mentioned subjects.

Table 3 summarizes the differences between the number of language hours in the two types of schools.

Table 2. Weekly hours of the language and literature courses in schools with Ukrainian and schools with Hungarian as the language of instruction in the 2015/2016 academic year

\begin{tabular}{|c|c|c|c|c|c|c|c|c|c|c|c|c|}
\hline \multicolumn{13}{|c|}{ Schools with Ukrainian as the language of instruction } \\
\hline \multirow{2}{*}{ Subjects } & \multicolumn{11}{|c|}{ hours per forms weekly / Forms } & \multirow{2}{*}{ Total } \\
\hline & 1 & 2 & 3 & 4 & 5 & 6 & 7 & 8 & 9 & 10 & 11 & \\
\hline $\begin{array}{l}\text { Ukrainian language (first } \\
\text { language }+ \text { state language) }\end{array}$ & 7 & 7 & 7 & 7 & 3.5 & 4 & 3 & 2 & 2 & 2 & 2 & 46.5 \\
\hline $\begin{array}{l}\text { Ukrainian (national) } \\
\text { literature }\end{array}$ & & & & & 2 & 2 & 2 & 2 & 2 & 2 & 2 & 14 \\
\hline Foreign language & 1 & 2 & 2 & 2 & 3 & 3 & 3 & 3 & 2 & 3,5 & 3,5 & 28 \\
\hline World literature & & & & & 2 & 2 & 2 & 2 & 2 & 2 & 2 & 14 \\
\hline Total & 8 & 9 & 9 & 9 & 10,5 & 10 & 9 & 8 & 8 & 9 & 9 & 98.5 \\
\hline \multicolumn{13}{|c|}{ Schools with Hungarian as the language of instruction } \\
\hline $\begin{array}{l}\text { Ukrainian language } \\
\text { (state language) }\end{array}$ & 3 & 3 & 4 & 4 & 3.5 & 4 & 3 & 2 & 2 & 2 & 2 & 32.5 \\
\hline $\begin{array}{l}\text { Ukrainian literature } \\
\text { (literature of the majority } \\
\text { nation) }\end{array}$ & & & & & 2 & 2 & 2 & 2 & 2 & 2 & 2 & 14 \\
\hline Foreign language & 1 & 2 & 2 & 2 & 3 & 2 & 2 & 2 & 2 & 3 & 3 & 24 \\
\hline First language (Hungarian) & 6 & 6 & 5 & 5 & 3 & 4 & 3 & 2 & 2 & 1 & 1 & 38 \\
\hline $\begin{array}{l}\text { Integrated literature } \\
\text { (national + world literature) }\end{array}$ & & & & & 2 & 2 & 2 & 2 & 2 & 2 & 2 & 14 \\
\hline Total & 10 & 11 & 11 & 11 & 13,5 & 14 & 12 & 10 & 10 & 10 & 10 & 122.5 \\
\hline
\end{tabular}


BILINGUAL EDUCATION OF MINORITIES: ALWAYS THE BEST SOLUTION?

Table 3. Difference between the number of language and literature hours in schools with Ukrainian and schools with Hungarian as the language of instruction in the academic year 2015/2016 (language and literature section)

\begin{tabular}{|l|r|r|r|}
\hline & \multicolumn{3}{|c|}{ Traditional school } \\
\cline { 2 - 5 } & $\begin{array}{l}\text { Ukrainian as the language of } \\
\text { instruction (majority=MA) }\end{array}$ & $\begin{array}{c}\text { Minority language as the } \\
\text { language of instruction (MI) }\end{array}$ & $\begin{array}{c}\text { Difference } \\
\text { (MA-MI) }\end{array}$ \\
\hline $\begin{array}{l}\text { First } \\
\text { language }\end{array}$ & 46.5 & 38 & $\mathbf{8 . 5}$ \\
\hline $\begin{array}{l}\text { State } \\
\text { language }\end{array}$ & 46.5 & 32.5 & $\mathbf{1 4}$ \\
\hline $\begin{array}{l}\text { Foreign } \\
\text { language }\end{array}$ & 28 & 24 & $\mathbf{4}$ \\
\hline
\end{tabular}

If we accept the fact that everybody has a mother tongue and we consider it natural that everybody has the right to learn their a) mother tongue, b) the state language and c) a foreign language at school, there is no way around it: rights a) and b) are both covered by the Ukrainian classes in Ukrainian schools. However, in the case of minority learners, the subject 'first language' clearly corresponds to a), and the subject 'Ukrainian language' corresponds to b). Both types of schools prescribe the teaching and learning of a foreign language c), though. It means that the amount of school work greatly differs for Ukrainian children and children with other mother tongues in Ukraine. In summary, much time, energy and money are spent teaching the state language, in the present conditions, still, it is not possible to learn the Ukrainian language at an adequate level. It is evident that both the purpose and the number of weekly hours differ in teaching 'Ukrainian language' in the two types of schools.

If a Transcarpathian Hungarian child has been studying the subject 'Ukrainian language' for eleven years (Forms 1-11) and still has virtually no or hardly any command of it, then we can take it for granted that the education system is bad. However, the solution is neither to make students study all school subjects in the majority language nor to introduce bilingual education. The possibilities that lead to a high level of language skills and additive bilingualism must be found within the framework of the school that uses the students' mother tongue as the language of instruction.

We see certain deficiencies in Kulyk's proposal of introducing bilingual schooling as well as in the mixed model of teaching the state lan- 
guage and the minority language. In the Transcarpathian Hungarian context, these models seem more idyllic than practical. If we take the first model described by Kulyk (2013: 640), the problem immediately becomes evident: the model provides only a communication-oriented course in Ukrainian in the first four years of schooling, so how can children aged 12 start learning academic disciplines like geometry, biology, geography, physics or chemistry (each with its own specific vocabulary) in Ukrainian without any prior knowledge of an academic Ukrainian vocabulary? It appears then that minority children become disadvantaged compared to their Ukrainian peers of the same age attending majority schools: while Ukrainian children are acquiring content, minority children will be still struggling with acquiring the necessary Ukrainian vocabulary to be able to learn the content. We consider it unfair and undemocratic, as minority children have the very same human rights as their majority peers.

\section{Consequences of low-efficiency language teaching}

Language teaching in Transcarpathian schools with Hungarian as the language of instruction is not at all efficient. A significant part of Transcarpathian Hungarian parents see this education as a segregation programme (Skutnabb-Kangas 1990: 14) that stops their children from successful integration and social mobility. Because of the low standard of teaching Ukrainian, more and more parents decide to have their children attend schools with Ukrainian as the language of instruction (Csernicskó 2013: 411-424). This is the so-called "submersion" or 'sink-or-swim' model (SkutnabbKangas 1990: 13). Skutnabb-Kangas \& Dunbar (2010) call this form of education a dangerous educational model for minorities, as it does not help maintain the ethno-linguistic identity of minorities; neither does it help form additive bilingualism. What it serves is assimilation. The segregation programme, however, does not help social integration either, as it does not result in additive bilingualism.

Our mutual responsibility and interest - that of the Ukrainian state and of Transcarpathian Hungarians - is that the schools with Hungarian as the language of instruction should facilitate integration rather than segregation, and that the education system fosters prosperity in the students' home country rather than prompts them to emigrate. 


\section{Conclusion: how could the problem be solved?}

There is no dispute between Kulyk and us in the notion that learning the state language is important and useful for Transcarpathian Hungarians. However, we firmly believe that learning the Ukrainian language is not the main goal. Acquisition of the state language is only a means of social integration. We are also certain that while preserving Hungarian schools, we have to find the educational model that facilitates the goals that Kulyk also regards as crucial: maintaining ethno-linguistic identity and the acquisition of Ukrainian at a level that makes successful social integration possible. On the other hand, we are also sure that besides these two goals, teaching all the other school subjects at a high level is of equal importance. We must not allow that teaching and learning Ukrainian gain higher importance than good quality school education, as in a well-functioning state, a good command of the state language is not the main requirement of social integration.

Instead of bilingual schooling as suggested by Kulyk, we would like to preserve the "language shelter (maintenance)" educational programme recommended by Skutnabb-Kangas (1990: 13-14). We are convinced that teaching Ukrainian in Transcarpathian schools with Hungarian as the language of instruction can only then be effective and fruitful if the state is willing to cooperate with the experts of the Hungarian minority.

\section{References:}

Csernicskó, I. 2011. The linguistic aspects of the Ukrainian educational policy. ESUKA - JEFUL 2-1: 75-91.

Csernicskó, I. 2013. Államok, nyelvek, államnyelvek. Nyelvpolitika a mai Kárpátalja területén (1867-2010) [States, languages, state languages. Language policy in present-day Transcarpathia (1867-2010)]. Budapest: Gondolat Kiadó.

Csernicskó, I. 2015. Teaching Ukrainian as a State Language in Subcarpathia: situation, problems and tasks. In Language learning and teaching: State language teaching for minorities, ed. I. Vančo and I. Kozmács, 11-23. Nitra: Univerzita Konštantina Filozofa v Nitre. 
Csernicskó, I. \& V. Ferenc. 2010. Education as an ideal means of achieving a nation state in Ukraine. In Concepts \& Consequences of Multilingualism in Europe, ed. J. Róka, 329-49. Budapest: Budapest College of Communication and Business.

Edwards, J. 1984. Language, diversity and identity. In Linguistic Minorities, Policies and Pluralism, ed. J. Edwards, 277-310. London: Academic Press.

Fishman, J. A. 1988/1992. The Displaced Anxieties of Anglo-Americans. In Language Loyalties: A sourcebook on the Official English controversy, ed. J. Crawford, 165-70. Chicago: The University of Chicago Press.

Kulyk, V. 2013. Combining identity and integration: comparative analysis of schools for two minority groups in Ukraine. Compare: A Journal of Comparative and International Education 43(5): 622-645.

LTI 2015. http://www.kmf.uz.ua/hun114/index.php/component/content/ article /48-friss-hirek/2071-a-2015-oes-erettsegifelveteli-eredmenyekrla-tanev-koezepen-bevezetett-uj-eljarasi-rendszer-fueggvenyeben. html (27-06-2015).

Patten, A. 2001. Political theory and language policy. Political Theory 29: 691-715.

Skutnabb-Kangas, T. 1990. Language, Literacy and Minorities. London: A Minorities Rights Group Report.

Skutnabb-Kangas, T. 1999. Education of Minorities. In Handbook of Language and Indentity, ed. J. A. Fishman, 42-59. Oxford: Oxford University Press.

Skutnabb-Kangas, T. \& J. Cummins. 1988. Concluding remarks: Language for empowerment. In Minority Education: From Shame to Struggle, eds. T. Skutnabb-Kangas and J. Cummins, 390-4. Clevedon-Philadelphia: Multilingual Matters.

Skutnabb-Kangas, T. \& R. Dunbar. 2010. Indigenous Children's Education as Linguistic Genocide and a crime Against Humanity? A Global View. Geaidnu/Kautokeino: Gáldu Č́la, Journal of Indigenous Peoples Rights no. 1/2010.

Skutnabb-Kangas, T., M. Kontra, \& R. Phillipson 2006. Getting Linguistic Human Rights Right: A Trio Respond to Wee (2005). Applied Linguistics 27: 318-324. 


\begin{abstract}
Many researchers firmly believe that the bilingual educational model can simultaneously preserve the ethno-cultural identity of the minorities under consideration and facilitate their social integration into the society. For Example, Volodymyr Kulyk outlined a proposal for solving the education problems of two minorities in Ukraine: the Crimean Tatars and the Transcarpathian Hungarians. He suggests launching bilingual education in these contexts. However, having researched the Transcarpathian Hungarian context from social, cultural, and sociolinguistic aspects for twenty years, we feel it necessary to respond to the issues described in the article by an internationally known expert. We emphasize that the issue of minority education is more complicated than described in the article mentioned above. We contribute to the discussion by presenting our insider views on the central issue.
\end{abstract}

Keywords: bilingual education, minority languages, state language, Transcarpathia, Ukraine.

\title{
Biographical statement
}

ISTVÁN CSERNICSKÓ was born in Chop, the westernmost town of the Soviet Union, in 1973. He received his university degree as a teacher of Hungarian language and literature at the Uzhgorod State University in independent Ukraine (1995), and his PhD (2001) and Habilitation (2012) at Eötvös Loránd University (ELTE) in Budapest (Hungary). He teaches at the Multilingualism Doctoral School (Core member) in the University of Pannonia (Veszprém, Hungary), ELTE's Doctoral School of Linguistics (Academic staff member), and Ferenc Rákóczi II Transcarpathian Hungarian Institute (Beregovo, Ukraine; associated professor), of which he is also director of Antal Hodinka Linguistic Research Centre (Beregovo, Ukraine).

E-mail: csernicsko.istvan@kmf.uz.ua

and csernicsko.istvan@gmail.com

Details and publications:

http://www.doktori.hu/index.php?menuid=502\&lang=EN 